\title{
Thienyl-phenyl Ethylenes with Crown Ether Fragments and Their Photocyclization Products: UV-Vis, NMR, Redox Response for Complexation. A 18-Crown-6 Ether Restricted with a Tricyclic Aromatic Moiety
}

\author{
Anatoliy Botezatu, ${ }^{a}$ Sergey Tokarev $^{\text {b }}$ Yulia Sotnikova, ${ }^{a}$ Anna Moiseeva, ${ }^{a}$ \\ Natalya Dyachenko, ${ }^{\mathrm{a}}$ Alexander Anisimov ${ }^{\mathrm{a}}{ }^{\text {Yuri Fedorov, }}{ }^{\mathrm{b}}$ Andrey Khoroshutin ${ }^{\mathrm{a}, \mathrm{c}}$ \\ and Olga Fedorovab ${ }^{\mathrm{b}}$

\footnotetext{
a Department of Chemistry, M.V. Lomonosov Moscow State University, 119991 Moscow, Russia

${ }^{\mathrm{b}}$ A.N. Nesmeyanov Institute of Elementoorganic Compounds of Russian Academy of Sciences, 119334 Moscow, Russia 'All-Russian Institute of Scientific and Technical Information of Russian Academy of Sciences (VINITI), 125190 Moscow, Russia
} \\ ${ }^{\circledR}$ Corresponding author E-mail:fedorova@ineos.ac.ru
}

\begin{abstract}
The synthesis of new compounds possessing 18-crown-6 fragment is reported: 1-(2-thienyl)-2-(meta-benzo-18-crown-6) stilbene and 1-(3-thienyl)-2-(meta-benzo-18-crown-6)stilbene, as well as two isomeric products of Mallory cyclization of 2-thienylstilbene, containing a tricyclic fragment annulated to the crown ether moiety. Binding constants of these compounds with $\mathrm{Ca}^{2+}$ and $\mathrm{Ba}^{2+}$ have been measured. Besides, dependence of the ${ }^{1} \mathrm{H}$ NMR chemical shifts of both stilbenes and cyclization products on their binding to $\mathrm{Ba}^{2+}$ has been studied. Redox response on the complexation is also elucidated. Among the studied compounds, a sterically congested photocyclization product exhibits an unusual dependence of chemical shifts upon complexation, as well as redox behaviour.
\end{abstract}

Keywords: Thienylstilbene, 18-crown-6, Mallory photocyclization, optical sensor, NMR sensor, redox sensor.

\section{Краун-содержащие тиенил-фенилэтилены и продукты их фотоциклизации: исследование комплексообразования. Конформационные ограничения 18-краун-6 эфира аннелированным трициклическим ароматическим фрагментом}

\author{
А. Ботезату, ${ }^{\text {a }}$ C. А. Токарев, ${ }^{\text {b }}$ Ю. А. Сотникова, ${ }^{\text {a }}$ А. А. Моисеева, ${ }^{\text {a }}$ Н. А. Аьяченко, ${ }^{a}$ \\ А. В. Анисимов, ${ }^{a}$ Ю. В. Фёдоров, ${ }^{\text {b }}$ А. В. Хорошутин, ${ }^{\text {a,c }}$ О. А. Фёдорова ${ }^{\text {b }}$

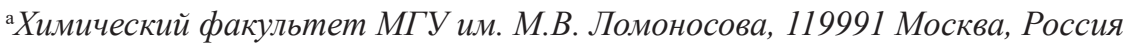 \\ ${ }^{\mathrm{b}}$ Институт элементоорганических соединений им. А.Н. Несмеянова РАН, 119334 Москва, Россия \\ 'Всероссийский институт научной и технической информаџии РАН, 125190 Москва, Россия \\ @E-mail: fedorova@ineos.ac.ru
}

\begin{abstract}
В настоящей работе синтезированы новые соединения, содержащие фрагменты 18-краун-6: 1-(2-тиенил)2-(мета-бензо-18-краун-6)стильбен и 1-(3-тиенил)-2-(мета-бензо-18-краун-6)стильбен, а также продукты ичиклизации 2-тиенилстильбена по Мэллори, содержащие трициклический фрагмент, аннелированный ккраунэфиру. Методом спектрофотометрического титрования измерень константы их комплексообразования с ионами $\mathrm{Ca}^{2+}$ и $\mathrm{Ba}^{2+}$. Кроме того, методом ЯМР титрования изучено влияние связывания краун-эфирного фрагмента с ионом $\mathrm{Ba}^{2+}$ на химические сдвиги как стильбенов, так и трициклических ароматических соединений, а также влияние колплексообразования на окислительно-восстановительные свойства. Среди изученных соединений стерически затруднённый краун-содержашций продукт фотоциклизации
\end{abstract}


проявляет аномальные свойства как по данным ЯМР титрования, так и по данным электрохимических экспериментов. Это может быть связано с искажением конформации краун-эфира под влиянием близости нафтотиофенового фрагмента.

Ключевые слова: Тиенилстильбен, 18-краун-6, фотоциклизация по Мэллори, оптический сенсор, ЯМР сенсор, редокс сенсор.

\section{Introduction}

Crown ether compounds have been widely studied ${ }^{[1-3]}$ since their discovery in $1969 .{ }^{[4]}$ Nowadays crown ethers are built in more complex electrochemical, ${ }^{[5-6]}$ fluorescence ${ }^{[7]}$ sensing systems, and parts of HPLC sorbents. ${ }^{[8]}$ They have plenty of applications, including, but not limited to, sensors for ions and neutral molecules, ${ }^{[9]}$ drug-delivery ${ }^{[10]}$ and complex supramolecular systems such as nanomachines and tunable catalysts. ${ }^{[1]}$ Also, crown ethers attached to metal complexes with $\pi$-extended molecules enable the control of macro properties of the films they constitute, ${ }^{[12]}$ build a variety of architectures. ${ }^{[13]}$ Sensibility of a molecule depends on a variety of factors, such as ligand-analyte binding constants and the sensitivity of the reporting group to the complex formation. Crown containing stilbenes possessing extended $\pi$-system capable of charge transfer excited state are especially interesting, because absorption wavelength is very sensitive to complexation. ${ }^{[14]}$

Recently, our group has been involved in the synthesis of polycyclic aromatic molecules prospective as molecular electronics components. These molecules are synthesized from 1-thienyl-2-phenylethylenes via Mallory photocyclization. ${ }^{[15-16]}$ As it was shown earlier photocyclization of 1-(3-thienyl)-2-(3,4-(15-crown-5)phenyl)stilbene results in two crown ethers drastically different in the position of the tricyclic moiety formed with respect to crown moiety. ${ }^{[17]}$ To the best of our knowledge, sensor properties neither of thienyl-phenyl stilbenes containing 18-crown-6 moiety, nor of these crown ethers with the attached tricyclic annelated aromatic fragments have been studied.

In the present paper we report the synthesis of novel 18-crown- 6 annelated 2-thienyl stilbenes, and their photocyclization products and the study of their sensor properties. As the $\mathrm{Ba}^{2+}$ is a benchmark ion for 18 -crown- 6 system, the first we have chosen is salts, and the salts of $\mathrm{Ca}^{2+}$ for the preliminary studies of the title compounds complexing ability, including the structural effects of the binding.

\section{Experimental}

All reagents were purchased from Sigma-Aldrich and Reakhim companies. Solvents were purchased from Ruskhim company and purified as described in the literature. ${ }^{[18]}$

NMR spectra were recorded on Bruker Avance 400 spectrometer, (400.13 and $100.13 \mathrm{MHz}$ frequency for ${ }^{1} \mathrm{H}$ and ${ }^{13} \mathrm{C}$, respectively). Chemical shifts are given with respect to the residual proton signal of the used solvent, i.e. $7.27 \mathrm{ppm}$ for $\mathrm{CDCl}_{3}$, $1.94 \mathrm{ppm}$ for $\mathrm{CD}_{3} \mathrm{CN}, 2.49 \mathrm{ppm}$ for DMSO- $d_{6}$ ), ${ }^{13} \mathrm{C}: 77.0 \mathrm{ppm}$ for $\mathrm{CDCl}_{3}, 1.24 \mathrm{ppm}$ for $\mathrm{CD}_{3} \mathrm{CN}$ ). High resolution mass spectra were measured with Bruker Maxis Impact and Thermo Scientific LTQ Orbitrap ${ }^{\left[{ }^{[1]}\right]}$ UV-Vis spectra were recorded on Cary 300 spectrometer, for the fluorescence spectra Cary Eclipse spectrofluorometer has been used. UV-Vis and fluorometric titration have been performed as follows: to $2.5 \mathrm{ml}$ of the $2 \cdot 10^{-5} \mathrm{M}$ solution of a titrant (organic ligand) portions of $10^{-3} \mathrm{M}$ and $10^{-2} \mathrm{M}$ of $\mathrm{Ba}\left(\mathrm{ClO}_{4}\right)_{2}$ or $\mathrm{Ca}\left(\mathrm{ClO}_{4}\right)_{2}$ solutions have been added successively to maintain a noticeable changes of a spectra of the resulting solution; the titration ended when there was no noticeable change of the spectrum upon the addition of the portion of the titration solution. Altogether, from 18 to 20 portions of a salt solution has been added, depending on the experiment, with the range of the titrant-analyte ratio varying from 0.2 to 10. Sets of the UV-Vis or fluorescence spectra have been processed by the SPECFIT 32 software. ${ }^{[20]}$

Starting stilbenes were synthesized from the 2-thenyland 3-thenylphosphonates $\mathbf{1}$ and $\mathbf{2}^{[21]}$ and the corresponding crown containing aldehyde $\mathbf{3}^{[22]}$ via Wittig-Horner-Emmons-Wadsworth reaction. ${ }^{[16,23-25]}$

Electrochemical measurements have been carried out with an IPC-Pro M potentiostat. Cyclic voltammetry (CVA) and rotating disc electrode (RDE) measurements were performed in a $10 \mathrm{~mL}$ cell with glassy carbon working electrode $(\mathrm{d}=2 \mathrm{~mm})$, platinum as counter electrode. $\mathrm{Ag} / \mathrm{AlCl} / \mathrm{KCl}$ (aq. saturated) has been used as reference electrode. The studied compound has been dissolved in the degassed solution of $0.1 \mathrm{M}$ of TBAP in $\mathrm{CH}_{3} \mathrm{CN}$. Scan rates were $100 \mathrm{mV} / \mathrm{s}$ and $20 \mathrm{mV} / \mathrm{s}$ for CVA and RDE measurements, respectively. Concentration of a ligand was $10^{-3} \mathrm{M}$, three scans have been made: that of solution of a pure ligand, 0.7 and 1.2 equivalents of $\mathrm{Ba}\left(\mathrm{ClO}_{4}\right)_{2}$.

Quantum chemical computations were carried out by Gaussian 09 program. ${ }^{[26]} 6-31+\mathrm{g}(\mathrm{d})$ basis set was selected for all 2- and 3-period atoms, for Ba atom Lan2LDZ basis set for outer shell and LanL2 pseudopotential for inner shell were used. B3LYP hybrid functional has been used.

18-[(E)-2-(2-Thienyl)vinyl]-2,3,5,6,8,9,11,12,14,15-decahydro-1,4,7,10,13,16-benzohexaoxacyclooctadecine (4). $223 \mathrm{mg}$ $(0.95 \mathrm{mmol})$ of 1 and $80 \mathrm{mg}$ of $\mathrm{NaH}(60 \%$ in mineral oil, $2 \mathrm{mmol})$ have been suspended in $10 \mathrm{ml}$ of DME and stirred for $30 \mathrm{~min}$. Then, $300 \mathrm{mg}$ of $\mathbf{3}(0.88 \mathrm{mmol})$ have been added. Reaction mixture was stirred for $4 \mathrm{~h}$ at $40^{\circ} \mathrm{C}$ and then overnight at room temperature. Then, it was poured to water-ice mixture, the precipitate formed has been filtered and recrystallized from methanol $(15 \mathrm{ml})$. Yield: $350 \mathrm{mg}$ (34 \%). HRMS: Found $443.1490 \mathrm{C}_{22} \mathrm{H}_{28} \mathrm{O}_{6} \mathrm{~S}+\mathrm{Na}$ requires 443.1499. UV-Vis $\left(\mathrm{CH}_{3} \mathrm{CN}, 2 \cdot 10^{-5} \mathrm{M}\right) \lambda_{\max }(\lg \varepsilon) \mathrm{nm}: 239$ (3.50) sh, 339 (4.02). ${ }^{1} \mathrm{H}$ NMR $\left(\mathrm{CD}_{3} \mathrm{CN}\right) \delta_{\mathrm{H}} \mathrm{ppm}: 7.26\left(1 \mathrm{H}, \mathrm{d} J=5.6 \mathrm{~Hz}, \mathrm{H}_{5}{ }^{\prime \prime}\right)$, $7.26\left(1 \mathrm{H}, \mathrm{d} J=16.2 \mathrm{~Hz}, \mathrm{H}_{1}\right), 7.12\left(1 \mathrm{H}, \mathrm{d} J=1.8 \mathrm{~Hz}, \mathrm{H}_{17}\right), 7.08$ $\left(1 \mathrm{H}, \mathrm{d} J=3.6 \mathrm{~Hz}, \mathrm{H}_{3}{ }^{\prime \prime}\right), 7.05-6.98\left(2 \mathrm{H}, \mathrm{m}, \mathrm{H}_{19}, \mathrm{H}_{4^{\prime}}\right), 6.91(1 \mathrm{H}, \mathrm{d} J$ $\left.=16.2 \mathrm{~Hz}, \mathrm{H}_{2}\right), 6.89\left(1 \mathrm{H}, \mathrm{d} J=8.2 \mathrm{~Hz}, \mathrm{H}_{20}\right), 4.23-4.17\left(2 \mathrm{H}, \mathrm{m} \mathrm{H}_{2}\right.$ or $\left.\mathrm{H}_{15}\right), 4.17-4.11\left(2 \mathrm{H}, \mathrm{m} \mathrm{H}_{15}\right.$ or $\left.\mathrm{H}_{2}\right), 3.79-3.71\left(4 \mathrm{H}, \mathrm{m}, \mathrm{H}_{3}\right.$ and $\left.\mathrm{H}_{14}\right)$, 3.63-3.65 (8H, m, $\left.\mathrm{H}_{5,6,11,12}\right), 3.54\left(4 \mathrm{H}, \mathrm{s}, \mathrm{H}_{8,9}\right) .{ }^{13} \mathrm{C} \mathrm{NMR}\left(\mathrm{CDCl}_{3}\right) \delta_{\mathrm{C}}$ ppm: 148.8, 148.7, 143.0, 130.4, 128.0, 127.5, 125.5, 123.8, 120.2, 113.6, 111.2, 70.7, 70.60, 70.56, 69.48, 68.9, 68.0. (InChI-Key: RGCKPGTWXFPRFZ-HWKANZROSA-N).

18-[(E)-2-(3-Thienyl)vinyl]-2,3,5,6,8,9,11,12,14,15-decahydro-1,4,7,10,13,16-benzohexaoxacyclooctadecine (5). The same procedure as for $4.2(116 \mathrm{mg}, 0.50 \mathrm{mmol}), 3(150 \mathrm{mg}, 0.44 \mathrm{mmol})$, $\mathrm{NaH}$ (60 mg of $60 \%$ suspension, $1.5 \mathrm{mmol}$ ), $5 \mathrm{ml}$ of DMF. Yield $72 \mathrm{mg}, 39 \%$. HRMS: Found $443.1490 \mathrm{C}_{22} \mathrm{H}_{28} \mathrm{O}_{6} \mathrm{~S}+\mathrm{Na}$ requires 443.1499. UV-Vis $\left(\mathrm{CH}_{3} \mathrm{CN}, 2 \cdot 10^{-5} \mathrm{M}\right) \lambda_{\text {max }}$ (lge) nm: 216 (3.84), 234 (3.71) sh, 288 (3.90) sh, 298 (3.97), 310 (4.01). ${ }^{1} \mathrm{H} \mathrm{NMR}\left(\mathrm{CDCl}_{3}\right)$ $\delta_{\mathrm{H}}$ ppm: 7.35-7.30 $\left(2 \mathrm{H}, \mathrm{AB}\right.$ part of ABX system $J_{4^{\prime \prime},{ }^{\prime \prime}}=5.1 \mathrm{~Hz}$, 
$\left.J_{2,, 5,}=1.2 \mathrm{~Hz}, J_{2,4^{\prime,}}=3.2 \mathrm{~Hz}, \mathrm{H}_{4,,}, \mathrm{H}_{5, "}\right), 7.23-7.18(1 \mathrm{H}, \mathrm{X}$ part of ABX system, $\left.\mathrm{H}_{2,}\right), 7.05\left(1 \mathrm{H}, \mathrm{d} J=1.9 \mathrm{~Hz}, \mathrm{H}_{17}\right), 7.01(1 \mathrm{H}$, dd $\left.J=8.2 \mathrm{~Hz}, 1.9 \mathrm{~Hz}, \mathrm{H}_{19}\right), 6.98\left(1 \mathrm{H}, \mathrm{d} J=16.2 \mathrm{~Hz}, \mathrm{H}_{2}\right), 6.88(1 \mathrm{H}$, d $\left.J=16.2 \mathrm{~Hz}, \mathrm{H}_{1}\right), 6.86(1 \mathrm{H}, \mathrm{d} J=8.2 \mathrm{~Hz}), 4.24-4.21(2 \mathrm{H}, \mathrm{m}$, $\left.\mathrm{H}_{2}\right), 4.20-4.17\left(2 \mathrm{H}, \mathrm{m}, \mathrm{H}_{15}\right), 3.98-3.93\left(4 \mathrm{H}, \mathrm{m}, \mathrm{H}_{3}, \mathrm{H}_{14}\right), 3.81-3.78$ $\left(4 \mathrm{H}, \mathrm{m}, \mathrm{H}_{5}, \mathrm{H}_{12}\right), 3.75-3.72\left(4 \mathrm{H}, \mathrm{m}, \mathrm{H}_{6}, \mathrm{H}_{11}\right), 3.70\left(4 \mathrm{H}, \mathrm{s}, \mathrm{H}_{8}, \mathrm{H}_{9}\right)$. ${ }^{13} \mathrm{C} \mathrm{NMR}\left(\mathrm{CDCl}_{3}\right) \delta_{\mathrm{C}}$ ppm: 149.0, 148.8, 140.2, 130.9, 128.4, 126.1, 124.8, 121.7, 121.2, 120.1, 113.9, 111.5, 70.9, 70.8, 69.7, 69.6, 69.1, 69.0. (InChI-Key: MRSXDUMCPZFFEZ-OWOJBTEDSA-N).

Photocyclization procedure. All photocyclization reaction were carried out in a photoreactor, containing a water-cooled quartz well, immersed into the cylinder-shaped flask equipped with a reflux condenser and an argon inlet. The well is thermostated with a water run external thermostat. In a typical experiment, a solution of $50 \mathrm{mg}$ $(0.12 \mathrm{mmol})$ of 4 in $100 \mathrm{ml}$ of benzene, $39.4 \mathrm{mg}(0.16 \mathrm{mmol})$ of $\mathrm{I}_{2}$ and $8.38 \mathrm{ml}$ of propylene oxide $(7.39 \mathrm{~g}, 0.12 \mathrm{~mol})$ have been placed to a photoreactor and reaction was carried out for $2 \mathrm{hr}$ in the stream of argon. Color of iodine has disappeared, and the reaction mixture has been evaporated. Combined residues of three $50 \mathrm{mg}$ runs were chromatographed on $\mathrm{SiO}_{2}$, eluent EtOAc-dioxane. $30 \mathrm{mg}(20 \%)$ of 6 and $60 \mathrm{mg}(40 \%)$ of 7 have been isolated.

$2,3,5,6,8,9,11,12,14,15$-Decahydrothieno [2', 3' ':7,8] naphtho[1,2-b][1,4,7,10,13,16]hexaoxacyclooctadecine (6). HRMS: Found 441.1344 $\mathrm{C}_{22} \mathrm{H}_{26} \mathrm{O}_{6} \mathrm{~S}+\mathrm{Na}$ requires 441.1342. UV-Vis $\left(\mathrm{CH}_{3} \mathrm{CN}, 2 \cdot 10^{-5} \mathrm{M}\right) \lambda_{\max }(\lg \varepsilon) \mathrm{nm}: 242$ (4.22), 265 (3.91), 299 (3.50), 310 (3.49), 324 (3.18) sh, 341 (3.09). ${ }^{1} \mathrm{H}$ NMR $\left(\mathrm{CD}_{3} \mathrm{CN}\right) \delta_{\mathrm{H}} \mathrm{ppm}$ : $8.62\left(1 \mathrm{H}, \mathrm{dd} J=4.70 .8 \mathrm{~Hz}, \mathrm{H}_{23}\right), 7.83\left(1 \mathrm{H}, \mathrm{dd} J=8.80 .8 \mathrm{~Hz}, \mathrm{H}_{20}\right)$, $7.73\left(1 \mathrm{H}, J=8.9 \mathrm{~Hz}, \mathrm{H}_{18}\right.$ or $\left.\mathrm{H}_{17}\right), 7.71\left(1 \mathrm{H}, \mathrm{d} J=8.8 \mathrm{~Hz}, \mathrm{H}_{19}\right), 7.66$ $(1 \mathrm{H}, \mathrm{d} J=8.9 \mathrm{~Hz}), 7.38\left(1 \mathrm{H}, \mathrm{d} J=8.9 \mathrm{~Hz}, \mathrm{H}_{17}\right.$ or $\left.\mathrm{H}_{18}\right), 4.30-4.25$ (4H, m), 4.07-4.02 (2H, m), 3.90-3.85 (2H, m), 3.76-3.72 (2H, $\mathrm{m}), 3.70-3.62(6 \mathrm{H}, \mathrm{m}), 3.62-3.56(4 \mathrm{H}, \mathrm{m}$, all signals of the crown ether moiety $4.30-3.56$, unassigned). ${ }^{13} \mathrm{C} \mathrm{NMR}\left(\mathrm{CD}_{3} \mathrm{CN}\right) \delta_{\mathrm{C}} \mathrm{ppm}$ : $143.09,142.72,138.57,132.04,127.25,126.53,124.68,124.48$, $124.32,124.28,118.59,114.21,71.68,70.61,70.06,69.95,69.88$, 69.75, 69.53, 69.39, 69.17, 68.62. (InChI-Key: NSAOQXLYODCZSD-UHFFFAOYSA-N)

$8,9,11,12,14,15,17,18,20,21$-Decahydrothieno [2',3':7,8] naphtho[2,3-b][1,4,7,10,13,16] hexaoxacyclooctadecine HRMS: Found $441.1333 \mathrm{C}_{22} \mathrm{H}_{26} \mathrm{O}_{6} \mathrm{~S}+\mathrm{Na}$ requires 441.1342. UV-Vis $\left(\mathrm{CH}_{3} \mathrm{CN}, 2 \cdot 10^{-5} \mathrm{M}\right) \lambda_{\max }(\lg \varepsilon) \mathrm{nm}: 249$ (3.25), 290 (3.40), 301 (3.41), 322 (3.15), 337 (3.27). ${ }^{1} \mathrm{H}$ NMR $\left(\mathrm{CD}_{3} \mathrm{CN}\right) \delta_{\mathrm{H}} \mathrm{ppm}: 8.03(1 \mathrm{H}, \mathrm{dd}$ $\left.J=5.50 .7, \mathrm{H}_{1}\right), 7.83\left(1 \mathrm{H}, \mathrm{dd} J=8.70 .7, \mathrm{H}_{4}\right), 7.75\left(1 \mathrm{H}, \mathrm{s}, \mathrm{H}_{6}\right.$ or $\left.\mathrm{H}_{23}\right)$, $7.69\left(1 \mathrm{H}, \mathrm{dd} J=5.50 .4, \mathrm{H}_{2}\right), 7.68\left(1 \mathrm{H}, \mathrm{d} J=8.7, \mathrm{H}_{5}\right), 7.41\left(1 \mathrm{H}, \mathrm{s}, \mathrm{H}_{23}\right.$ or $\left.\mathrm{H}_{6}\right), 4.41-4.37\left(2 \mathrm{H}, \mathrm{m}, \mathrm{H}_{8}\right.$ or $\left.\mathrm{H}_{21}\right), 4.32-4.28\left(2 \mathrm{H}, \mathrm{m}, \mathrm{H}_{21}\right.$ or $\left.\mathrm{H}_{8}\right)$, 3.92-3.85 (4H, m, $\left.\mathrm{H}_{9,20}\right), 3.69-3.63\left(4 \mathrm{H}, \mathrm{m}, \mathrm{H}_{11,18}\right), 3.63-3.58(4 \mathrm{H}$, $\left.\mathrm{m}, \mathrm{H}_{12,17}\right), 3.57\left(4 \mathrm{H}, \mathrm{s}, \mathrm{H}_{14,15}\right) .{ }^{13} \mathrm{C} \mathrm{NMR}\left(\mathrm{CD}_{3} \mathrm{CN}\right) \delta_{\mathrm{C}} \mathrm{ppm}: 149.32$, $148.34,136.71,136.06,127.05,126.84,125.34,124.74,122.91$, $119.69,109.06,104.96,70.72,70.61,69.46,69.43,68.40,68.14$. (InChI-Key: RYTJURGZEYWYDH-UHFFFAOYSA-N).

\section{Results and Discussion}

The studied compounds have been synthesized by well established Wittig-Horner-Emmons procedure from 3-thenyl- and 2-thenylphosphonates $(\mathbf{1}, \mathbf{2})$ and 3-formylbenzo-18-crown-6 (3) (Scheme 1). Despite reasonable simplicity of these compounds, they have not been reported in the literature, their identity has been confirmed by NMR and mass spectrometry. Trans orientation of the double bond is evidenced by a characteristic coupling constant $(16 \mathrm{~Hz})$, cis-isomer has not been detected.

Photocyclization of thienylstilbene 4 in Katz conditions yielded two isomers arising from the rotation of ${ }^{1} \mathrm{C}-{ }^{18} \mathrm{C}$ bond (Scheme 2).

Two isomers 6 and 7 possess the expected differences in the aromatic region, i.e. three doublets $v s$ two doublets and one singlet, respectively. Of more interest is that the crown ether part of $\mathbf{6}$ differs from that of $\mathbf{7}$ (Figure 1). The isomer 7 exhibits an usual pattern of the benzo crown ether. On the contrary, no singlet, analogous to that at $3.57 \mathrm{ppm}$ of 7, resulting from the protons $\mathrm{H}^{8,9}$ that are the most distant from the benzo ring is observed. The AA'BB' pattern is seen instead, being the evidence of the hindered conformational motion of this fragment. Straightforward assignment of the signals at 4.39 and $4.30 \mathrm{ppm}$ as those of $\mathrm{H}^{8}$ and $\mathrm{H}^{21}$ of 7 and all other groups of the signals that are all integrated as 4 protons as $\mathrm{H}^{11,18}, \mathrm{H}^{12,17}, \mathrm{H}^{8,9}$ is not possible for $\mathbf{6}$. Instead, all the signals are shifted upfield and distributed in a different way among the groups with different integral intensities. Most plausible explanation of the conformational motion
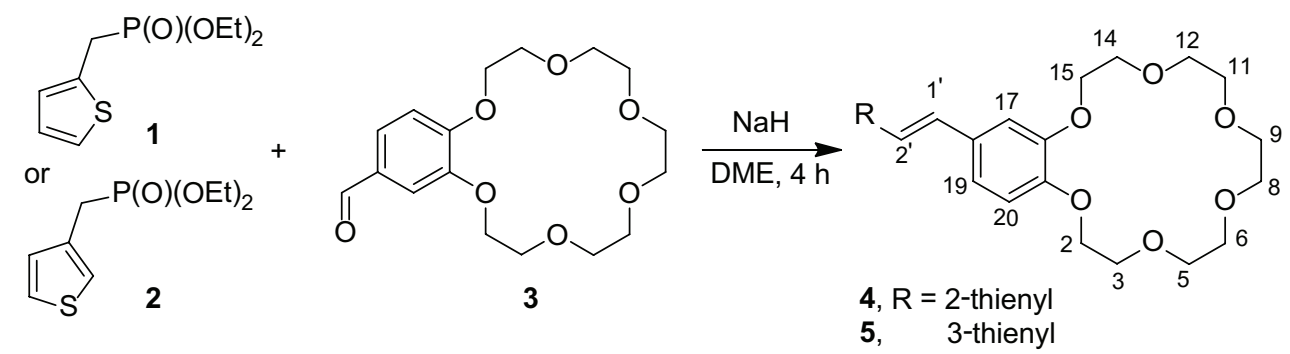

Scheme 1.
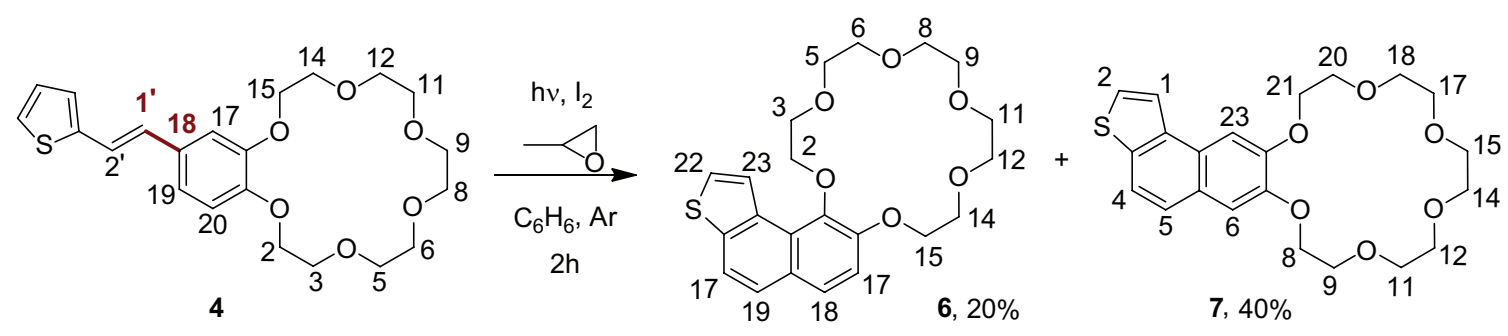

Scheme 2 .

Макрогетероцикль / Macroheterocycles 2020 13(2) 163-171 


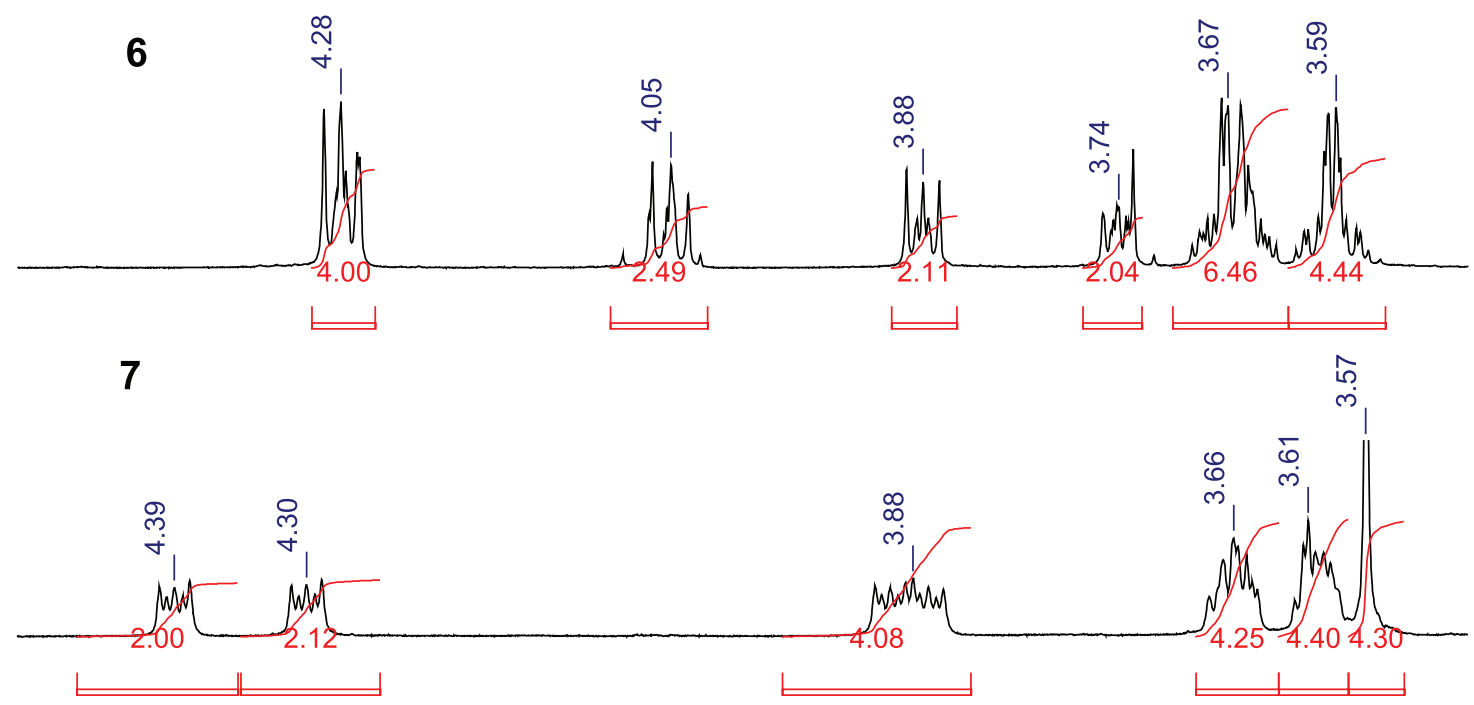

Figure 1. ${ }^{1} \mathrm{H}$ NMR spectra of 6 and 7, crown ether region.

hindrance is the proximity of the aromatic fragment; upfield shift is an anisotropic influence of the fragment.

UV-Vis spectra of the cyclization products (6, 7) show prominent hypsochromic shift with respect to that of the initial stilbene (4). Absorption maximum of 5 is shifted to higher energies indicating less delocalization than in 4. Both isomers 6 and 7 do have similar UV-Vis spectra, differing in the $264 \mathrm{~nm}$ band of $\mathbf{6}$ on the right side of the principal UV band.

Stilbenes show much bigger Stokes shift (4250 and $4150 \mathrm{~cm}^{-1}$ for 4 and 5, respectively, see Figures 2, 3) than the tricyclic aromatics (990 and $350 \mathrm{~cm}^{-1}$ for 6 and 7 , respectively, see Figures 2, 4).

To elucidate possible analytical signals that are generated upon complexation of 4-7 with alkali earth metals we performed UV-Vis, ${ }^{1} \mathrm{H}$ NMR, redox and fluorescence titration experiments.

\section{UV-Vis and Fluorescence Titration}

Addition of the titrant - barium and calcium perchlorates - causes small detectable changes of the analyte

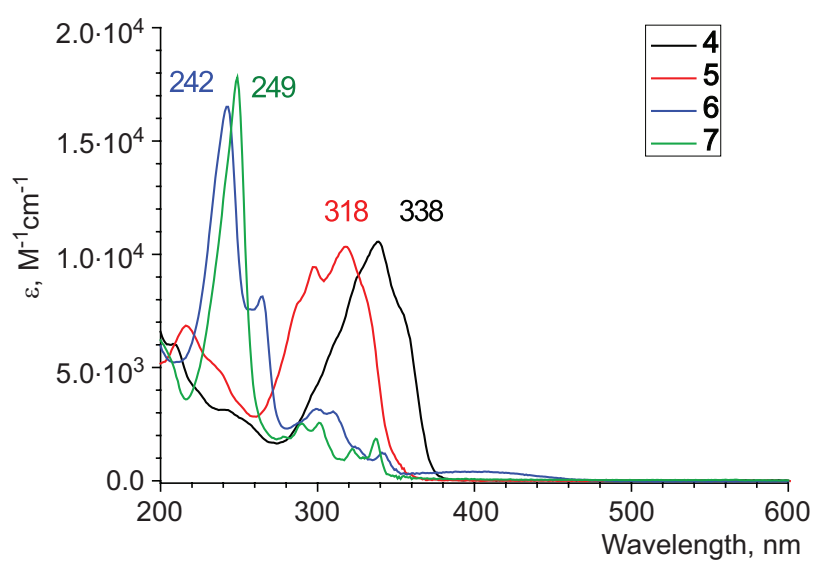

Figure 2. UV-Vis spectra of 4, 5, 6 and $7\left(\mathrm{CH}_{3} \mathrm{CN}, 2 \cdot 10^{-5} \mathrm{M}\right)$.

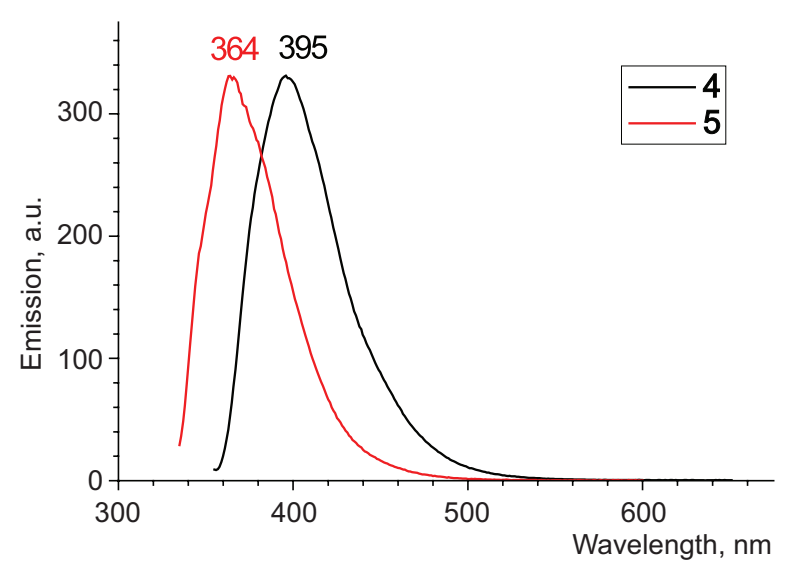

Figure 3. Fluorescence spectra of $\mathbf{4}$ and $\mathbf{5}\left(\lambda_{\mathrm{ex}}=330 \mathrm{~nm}\right.$, $\left.2 \cdot 10^{-5} \mathrm{M}\right)$.

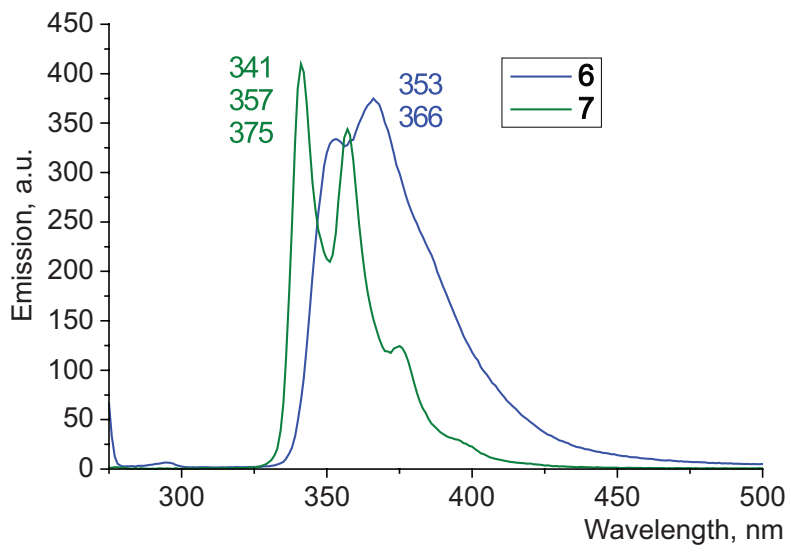

Figure 4. Fluorescence spectra of 6 and $7\left(\lambda_{\text {ex }}=330 \mathrm{~nm}\right.$, $\left.2 \cdot 10^{-5} \mathrm{M}\right)$.

spectra. A decrease of the absorption is observed at the right side of the absorption band of 4 and 5 (Figure 5). This is quite in analogy with the previously studied 15-crown-5- 
benzo-2-thienyl stilbene, ${ }^{[27]}$ the absorption band of which has little charge transfer character, as the substituents at the double bond of stilbene are close in electronegativity. Further, absorption spectrum intensity of $\mathbf{6}$ increases upon the addition of $\mathrm{Ba}^{2+}$ (Figure 6 ) and $\mathrm{Ca}^{2+}$ (not shown), whereas that of 7 decreases (Figure 7). Fluorescence intensity for both 6 and 7 diminishes in the presence of the salts, perhaps due to increased number of vibrational relaxation modes in the complex compared to an unbound ligand. These data allow for the calculation of the binding constants by the algorithm realized in the SPECFIT program ${ }^{[20]}$ assuming 1:1 composition. ${ }^{[28]}$ (Table 1). However, the processing of the fluorescence spectra of $\mathbf{4}$ and $\mathbf{5}$ did not yield reliable results, perhaps due to photoisomerization of stilbenes.

Binding constants of all 18-crown-6 substrates are expectedly lower for calcium than for barium which correlates with better correspondence of barium to the 18-crown- 6 ether cavity. ${ }^{[29]}$ Constants measured by different methods coincide within the measurements accuracies.
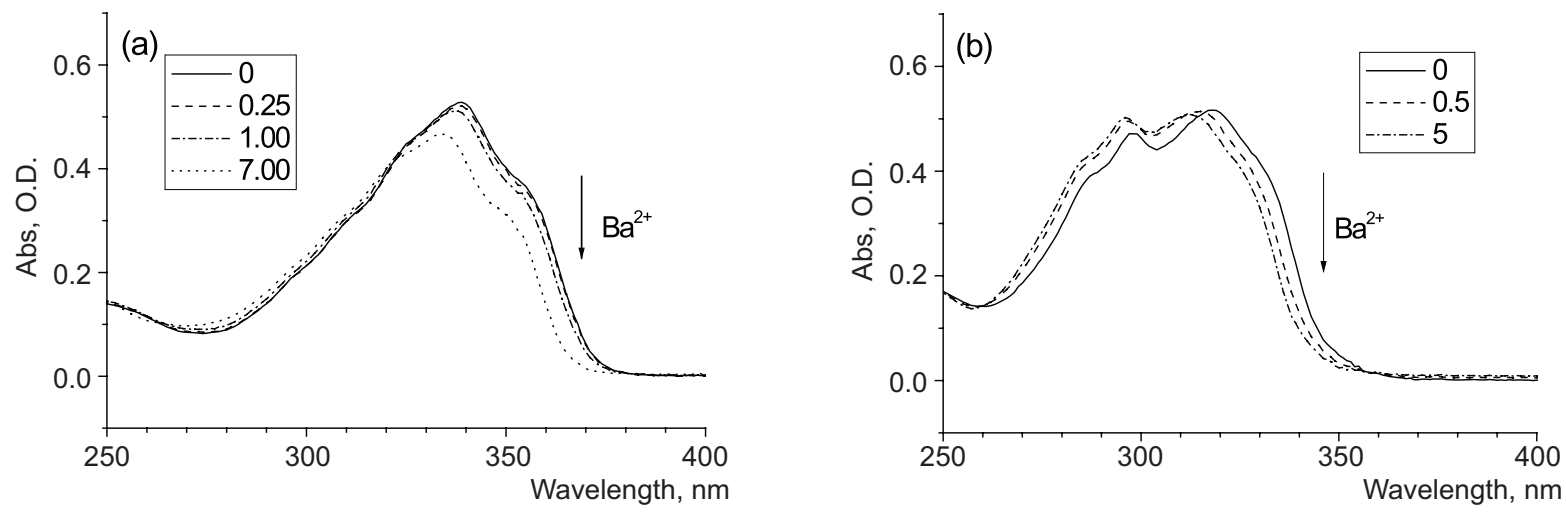

Figure 5. Absorption titration of (a) 4 and (b) 5 with $\mathrm{Ba}\left(\mathrm{ClO}_{4}\right)_{2}\left(2 \cdot 10^{-5} \mathrm{M}\right)$, the ratios titrant:analyte are shown in the legend.
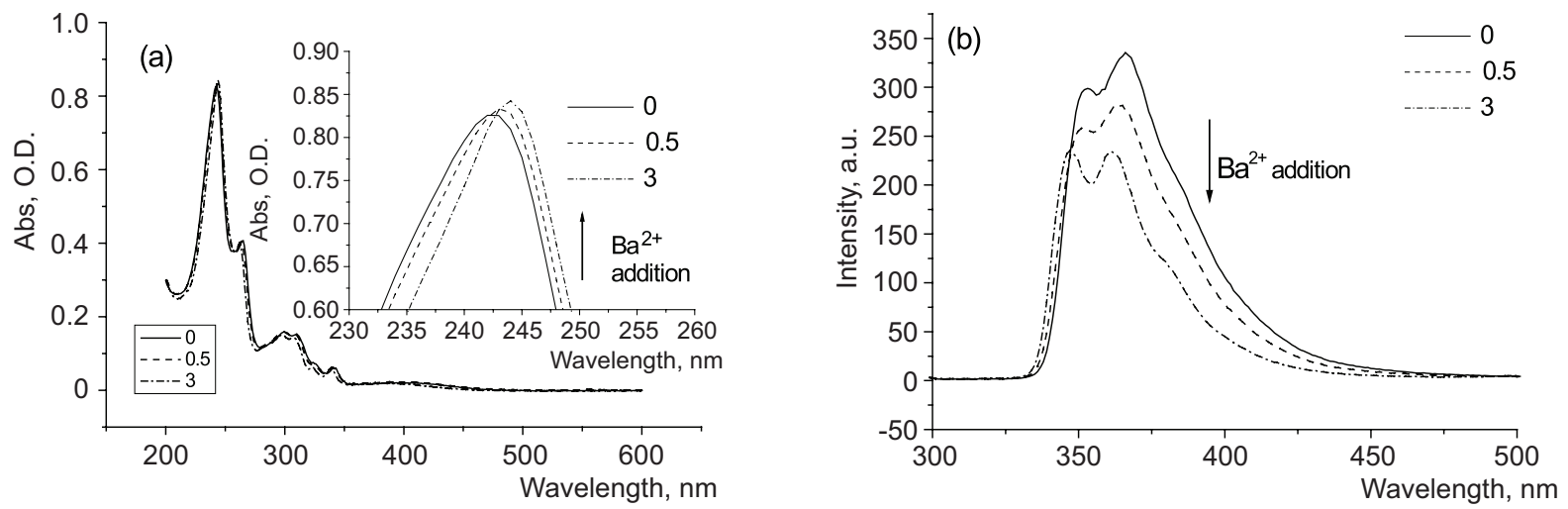

Figure 6. Absorption (a) and fluorescence (b) titration of 6 with $\mathrm{Ba}\left(\mathrm{ClO}_{4}\right)_{2}\left(\lambda_{\mathrm{ex}}=330 \mathrm{~nm}, 2 \cdot 10^{-5} \mathrm{M}\right.$, solid, dashed, dash dotted lines for 0 , 0.5 and 3 equivalents added, respectively).
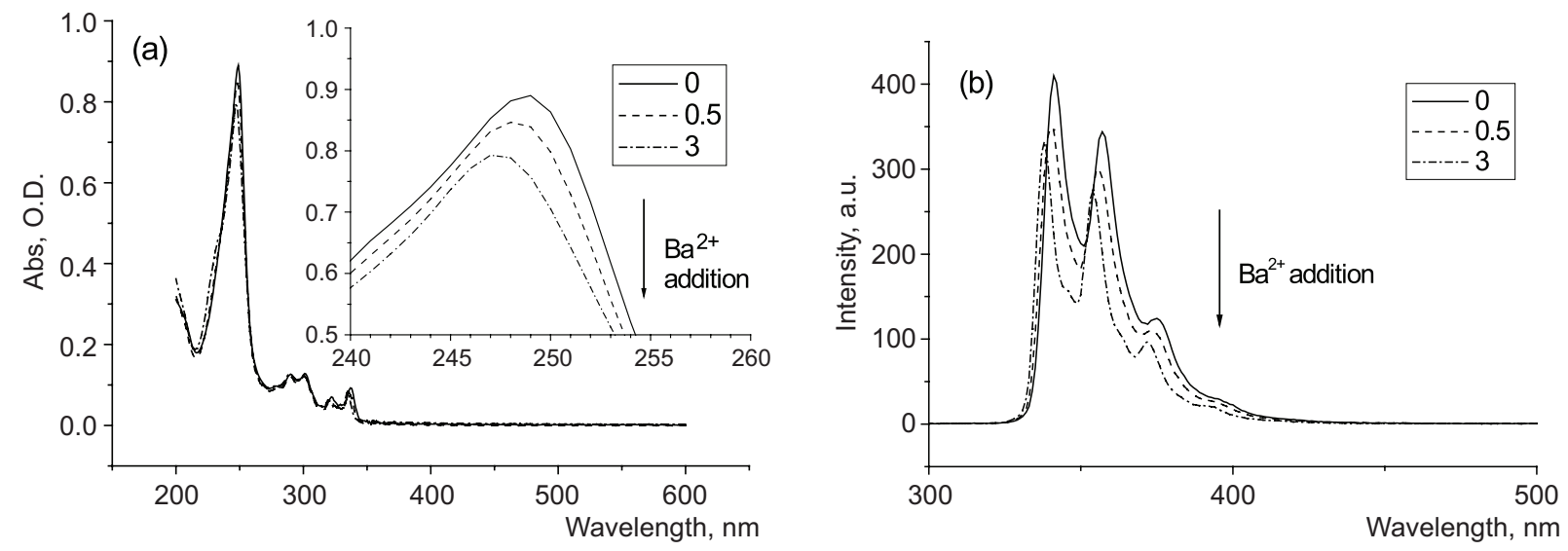

Figure 7. Absorption (a) and fluorescence (b) titration of 7 with $\mathrm{Ba}\left(\mathrm{ClO}_{4}\right)_{2}\left(\lambda_{\text {ex }}=330 \mathrm{~nm}, 2 \cdot 10^{-5} \mathrm{M}\right.$, solid, dashed, dash dotted lines for 0 , 0.5 and 3 equivalents added, respectively). 
Table 1. Logarithms of the binding constants of $\mathrm{Ca}^{2+}$ and $\mathrm{Ba}^{2+}$ perchlorates to 4, 5, 6 and 7 measured by optical methods.

\begin{tabular}{ccccc}
\hline \multirow{2}{*}{ Compound } & \multicolumn{2}{c}{$\mathrm{Ca}\left(\mathrm{ClO}_{4}\right)_{2}$} & \multicolumn{2}{c}{$\mathrm{Ba}\left(\mathrm{ClO}_{4}\right)_{2}$} \\
\cline { 2 - 5 } & Abs & Fluo & Abs & Fluo \\
\hline $\mathbf{4}$ & $5.0 \pm 0.1$ & - & $5.7 \pm 0.2$ & - \\
$\mathbf{5}$ & $5.0 \pm 0.1$ & - & $5.3 \pm 0.2$ & - \\
$\mathbf{6}$ & $5.4 \pm 0.2$ & $5.4 \pm 0.3$ & $6.0 \pm 0.2$ & $6.3 \pm 0.1$ \\
7 & $6.0 \pm 0.3$ & $6.4 \pm 0.3$ & $6.3 \pm 0.3$ & $6.0 \pm 0.1$ \\
\hline
\end{tabular}

\section{${ }^{1}$ H NMR Titration}

Portionwise addition of $\mathrm{Ba}\left(\mathrm{ClO}_{4}\right)_{2}$ to the solutions of 4, 5, 7 results in expected changes of the proton signals positions: 1. Both crown ether and aromatic/double bond resonances are moved downfield depending on their distance to the complexed ion (see Figure 8, right as the example); 2. Signals are broadened at the small amounts of the titrant (less that 1:1 titrant-analyte ratio), perhaps due to an exchange process; they become well resolved again at 1:1 and higher

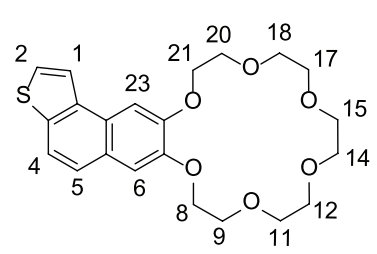

$\diamond 1 \square-\square \triangle 4 \times 5 \rightarrow 6-0-23$

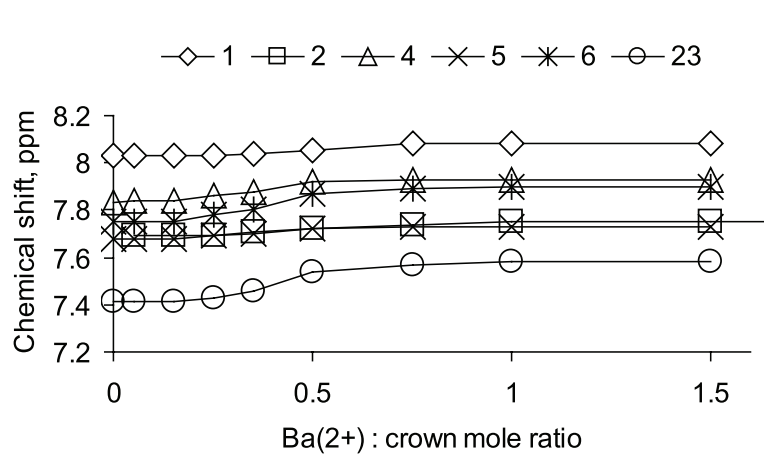

Figure 8. Changes of the NMR $\left(\mathrm{CD}_{3} \mathrm{CN}\right)$ of 6 (left) and 7 (right) upon the addition of $\mathrm{Ba}\left(\mathrm{ClO}_{4}\right)_{2}$.
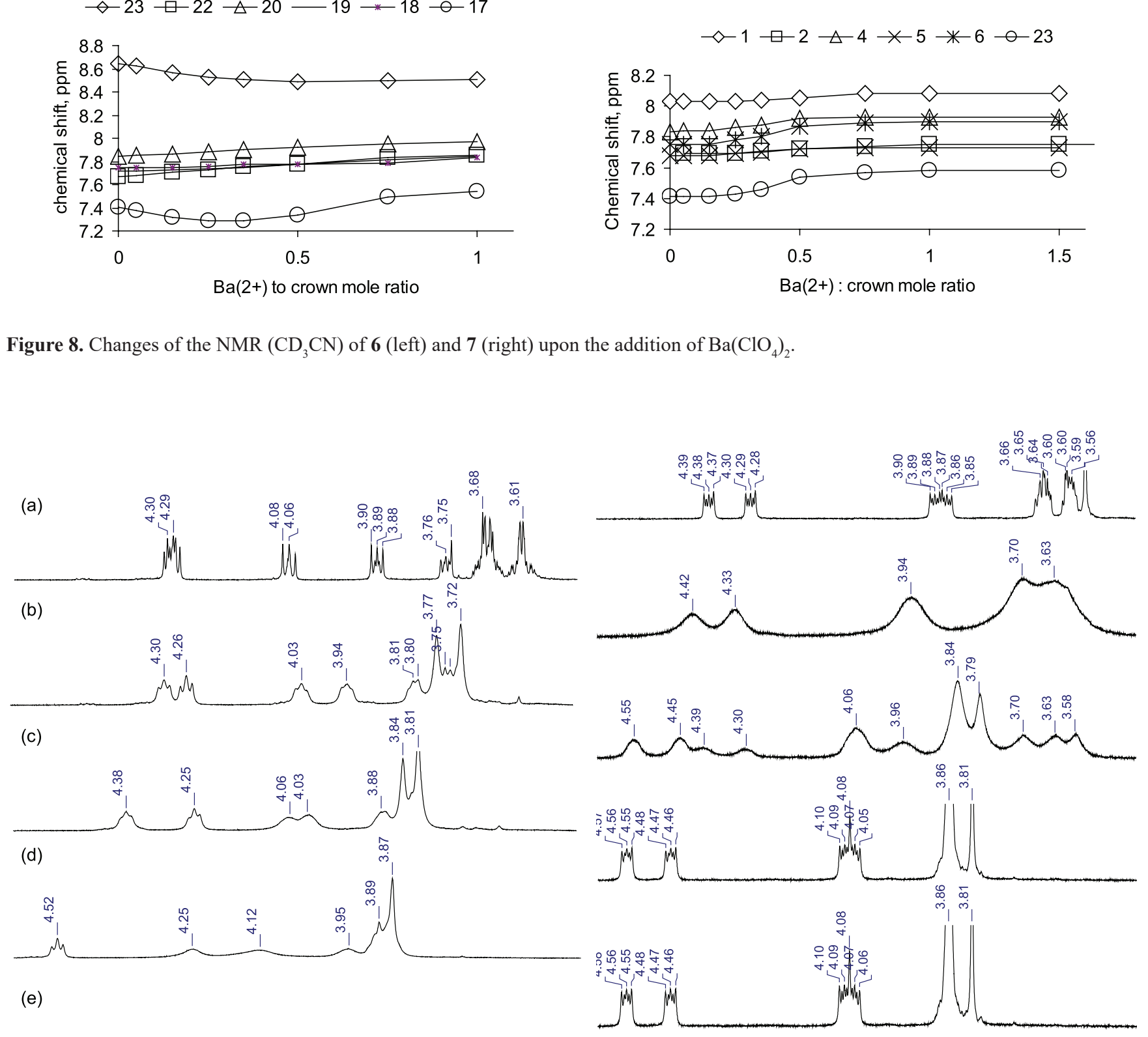

Figure 9. Changes of the NMR $\left(\mathrm{CD}_{3} \mathrm{CN}\right)$ of 6 (left) and 7 (right) upon the addition of $\mathrm{Ba}\left(\mathrm{ClO}_{4}\right)_{2}$. Titrant:analyte mole ratios: (a) - 0; (b) -0.25 ; (c) -0.5 ; (d) -1.0 ; (e) -1.5 . 
ratios; 3. No changes occur after addition of the salt excess. All these findings manifest formation of a non-labile 1:1 complex, known in the literature. ${ }^{[28]}$

However, titration of $\mathbf{6}$ show different pattern of chemical shift dependence on the added titrant. Signals of the heterocycle protons that are close to the crown ether moiety $\left(\mathrm{H}^{17}\right.$ and $\left.\mathrm{H}^{23}\right)$ are moved upfield, whereas distant ones do show moderate downfield drift. Addition of one equivalent of $\mathrm{Ba}\left(\mathrm{ClO}_{4}\right)_{2}$ to 6 (Figure 9, left) does not result in the appearance of the set of the resolved multiplets (Figure 9 , right), although shifted downfield. A picture characteristic of the titrant deficiency is seen. Tentative interpretation of this fact is that this may be the consequence of the steric overlap that prohibits formation of a fully symmetrical nonlabile $\mathrm{Ba}^{2+}$-crown ether complex.

As can be seen from the results of the quantum chemistry calculations (Figures 10a, 11a), the geometry of non-complexed $\mathbf{6}$ and $\mathbf{7}$ is quite different. This can be illustrated by the dihedral angles at the crown ether C-C bonds adjacent to the aromatic rings, denoted as Angle I and Angle II (Table 2, Figures 10, 11). Crown ether in 7 (Figure 11a) possesses rather symmetrical structure with the angles being approximately the same, differing in the sign only. Conversely, these angles in $\mathbf{6}$ are quite different, the Angle I being close to $90^{\circ}$, the Angle II being close to $180^{\circ}$. Such difference of the angle in $\mathbf{6}$ leads to more flattened shape of the crown ether than in 7. $\mathrm{Ba}^{2+}$ complexation of 7 leads to insignificant change of the crown ether atoms positions. On the contrary, crown ether fragment in the $6 \cdot \mathrm{Ba}^{2+}$ complex becomes more expanded in shape $v_{s} \mathbf{6}$, however, the steric reasons still prevent the Angle I to come

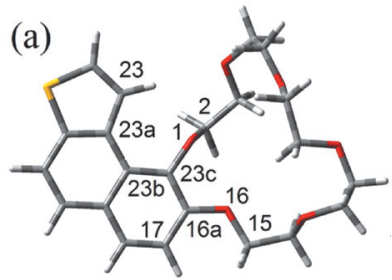

(b)

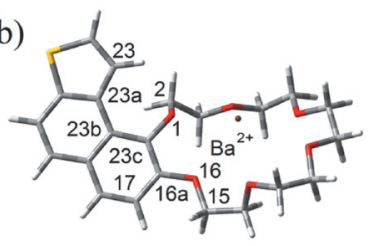

Figure 10. Optimized geometries of (a) 6 and (b) its complex with $\mathrm{Ba}^{2+}$. For (b) two $\mathrm{CH}_{3} \mathrm{CN}$ molecules used as additional ligands are not shown for clarity. Computational details see in the Experimental part.
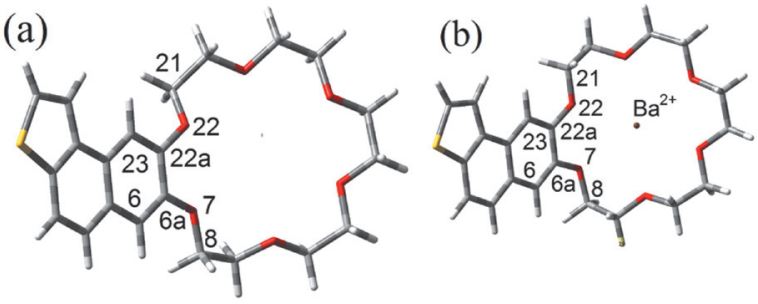

Figure 11. Optimized geometries of (a) 7 and (b) its complex with $\mathrm{Ba}^{2+}$. For (b) two $\mathrm{CH}_{3} \mathrm{CN}$ molecules used as additional ligands are not shown for clarity. Computational details see in the Experimental.
Table 2. Dihedral angles (Deg) of crown ether fragments proximate to the aromatic ring in non-complexed 6 and 7 and their $\mathrm{Ba}^{2+}$ complexes, according to DFT calculations.

\begin{tabular}{lcccc}
\hline & \multicolumn{2}{c}{6} & \multicolumn{2}{c}{7} \\
\cline { 2 - 5 } & Angle I & Angle II & Angle I & Angle II \\
& $23 b-23 c-1-2$ & $17-16 a-16-15$ & $23-22 a-22-21$ & $6-6 a-7-8$ \\
\hline Ligand & -105.7 & 171.1 & 4.7 & -4.2 \\
$\mathrm{Ba}^{2+}$ complex & -69.3 & -12.7 & -3.2 & -7.9 \\
\hline
\end{tabular}

to a value characteristic of near-plane arrangement of its constituent atoms.

These geometry differences of the free and complexed 6 and 7 also provide the insight into the reasons for hypsochromic shift of the UV-Vis spectra of $\mathbf{4}, \mathbf{5}$, and 7 upon complexation, and into the bathochromic effect of $\mathbf{6}$ upon the same. The geometry change of non-hindered 7 (Figure 11, Table 2), as well as of $\mathbf{4}$ and $\mathbf{5}$ (not shown) is negligible upon the complexation, and the hypsochromic shift of UV-Vis reflects less conjugation of oxygen atoms lone pairs with the $\pi$-system. On the contrary, substantial change of the dihedral angle $I$ in the complex $6 \cdot \mathrm{Ba}^{2+}$ with respect to the free 6 leads to more effective overlap of the $\mathrm{O}^{1}$ with the aromatic $\pi$-system (vide infra). This effect, perhaps, overcomes the diminished conjugation of the second oxygen atom $\left(\mathrm{O}^{16}\right)$ in $\mathbf{6} \cdot \mathrm{Ba}^{2+}$.

\section{Redox Titration}

Electrochemical response on the complexation was studied by cyclic voltammetry method (CVA). For all four compounds redox curves have been measured for the pure ligand, for 0.7 and for 1.2 equivalents of the titrant salt. These concentrations have been chosen: a) to obtain data for the deficiency and the excess of the titrant; b) to take into account the slow kinetics of the complex formation in the presence of the supporting electrolyte ( $c a .15 \mathrm{~min}$ ). For 4, 5, 7 all the redox curves had the same pattern, i.e. at the intermediate concentration of the titrant, redox peaks of both free ligand and complex forms for 4, 5, 7 are seen. The CVA of $\mathbf{7}$ is shown as the example in Figure 12.

On the contrary, oxidation curve of $\mathbf{6}$ does not show the presence of the free and the complexed forms. One can see an intermediate curve instead, showing no distinct potentials (Figure 13).

Redox experiments (Table 3) suggest that the crowncontaining stilbenes $\mathbf{4}, \mathbf{5}$ generally generate bigger response, i.e. the anode shift, on the addition of $\mathrm{Ba}\left(\mathrm{ClO}_{4}\right)_{2}$, than non-sterically congested annelated 7 (e.g. 100-250 $\mathrm{mV}$ vs $90 \mathrm{mV}$ ). 4 that has better electronic overlap than $\mathbf{5}$ yields slightly bigger anode shift. Response of steric congested $\mathbf{6}$ is approximately the same as that of $\mathbf{4}$ an $\mathbf{5}$. This phenomenon may be due to much bigger reorganization of the crown conformation in $\mathbf{6}$ than in $\mathbf{7}$ on the complexation, that yields a substantial change of the overlap of $\mathrm{O}^{1}$ lone pair with the rest of the annelated structure. Additionally, the absence of the peaks on the CVA curve of 6 and 0.7 eq. of $\mathrm{Ba}^{2+}$ may be caused by much more labile (i.e. exhibiting faster formation-decay kinetics) $6 \cdot \mathrm{Ba}^{2+}$ complex 

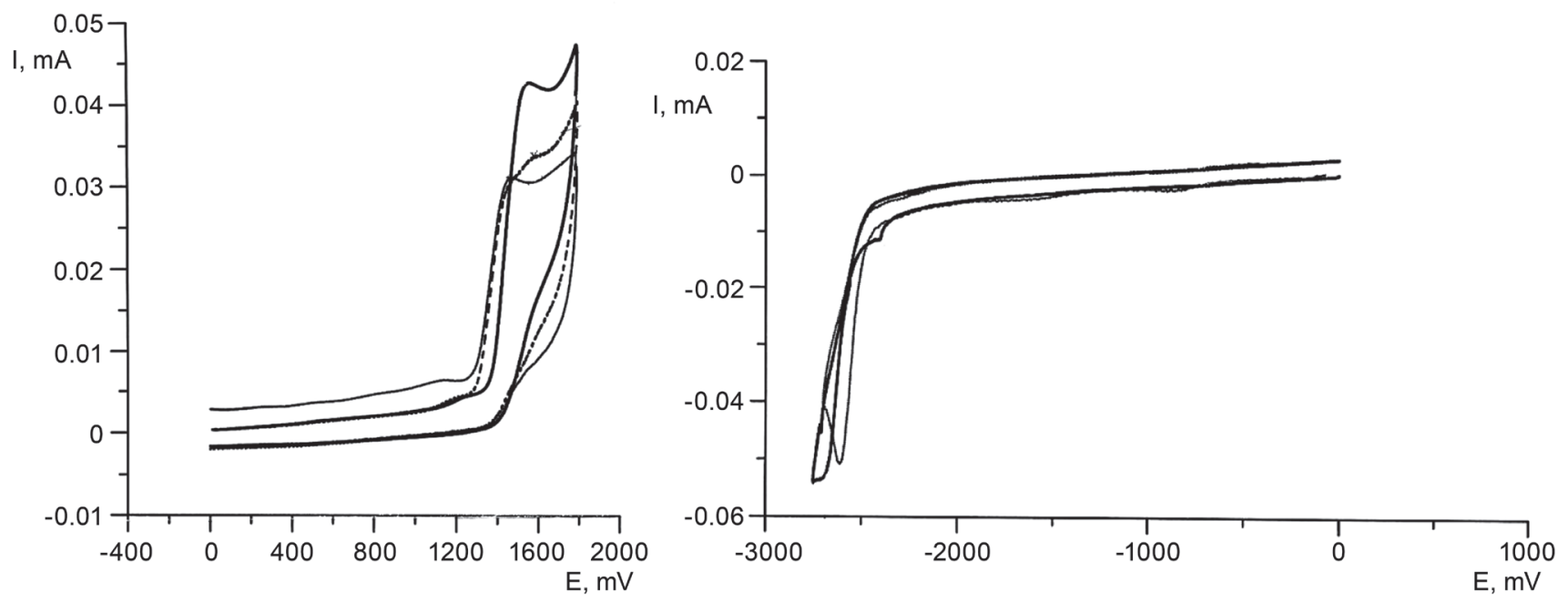

Figure 12. CVA oxidation (a) and reduction (b) curves of $7 v \mathrm{Ag} / \mathrm{AgCl} .\left(\mathrm{CH}_{3} \mathrm{CN}, \mathrm{C}=10^{-3} \mathrm{M}\right.$, supporting electrolyte $\mathrm{NBu}_{4} \mathrm{ClO}_{4}$, glass carbon electrode, scan rate $100 \mathrm{mV} / \mathrm{s})$. Grey $-\mathbf{7}$, dashed black $-7+0.7$ eq.; solid black $-7+1.2$ eq. of $\mathrm{Ba}\left(\mathrm{ClO}_{4}\right)_{2}$.

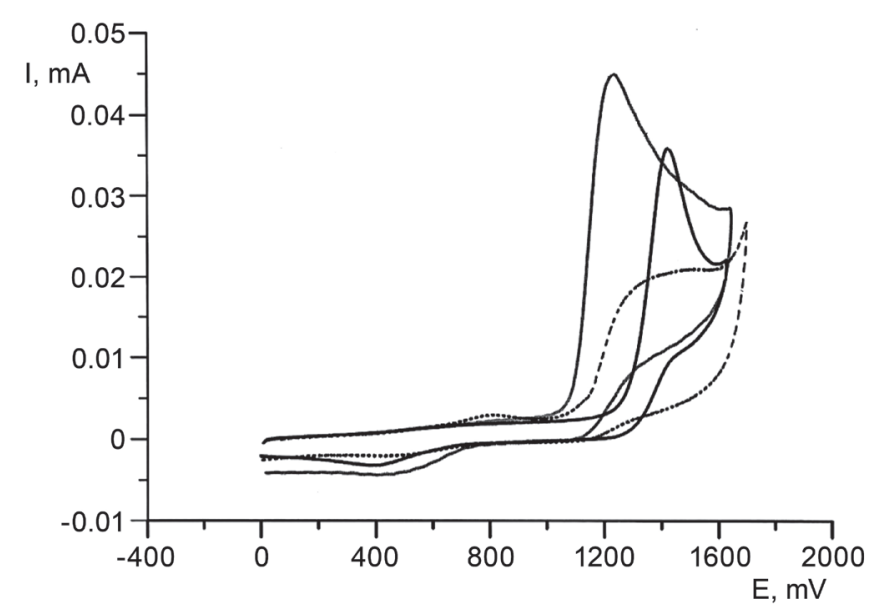

Figure 13. CVA oxidation (a) and reduction (b) curves of 6 vs $\mathrm{Ag} / \mathrm{AgCl}$. $\left(\mathrm{CH}_{3} \mathrm{CN}, \mathrm{C}=10^{-3} \mathrm{M}\right.$, supporting electrolyte $\mathrm{NBu}_{4} \mathrm{ClO}_{4}$, glass carbon electrode, scan rate $100 \mathrm{mV} / \mathrm{s}$ ). Grey $-\mathbf{6}$, dashed black $-\mathbf{6}+0.7$ eq; solid black $-\mathbf{6}+1.2$ eq of $\mathrm{Ba}\left(\mathrm{ClO}_{4}\right)_{2}$.

Table 3. CVA of the studied compounds $\left(10^{-3} \mathrm{M}, \mathrm{CH}_{3} \mathrm{CN}, 10^{-1} \mathrm{M}\right.$ $\left.\mathrm{NBu}_{4} \mathrm{ClO}_{4}\right)$, and their $\mathrm{Ba}\left(\mathrm{ClO}_{4}\right)_{2}$ complexes.

\begin{tabular}{ccccccc}
\hline & \multicolumn{3}{c}{ Oxidation, $\mathrm{V}$} & \multicolumn{4}{c}{ Reduction, $\mathrm{V}$} \\
& 0 eq. & 1.2 eq. & & 0 eq. & 1.2 eq. & $\Delta, \mathrm{mV}$ \\
\hline $\mathbf{4}$ & 1.08 & 1.23 & 150 & -2.28 & -2.04 & 240 \\
$\mathbf{5}$ & 1.05 & 1.15 & 100 & -2.43 & -2.22 & 210 \\
$\mathbf{6}$ & 1.234 & 1.424 & 190 & -2.57 & -2.72 & 150 \\
$\mathbf{7}$ & 1.46 & 1.55 & 90 & -2.6 & -2.69 & 90 \\
\hline
\end{tabular}

than those of $\mathrm{Ba}^{2+}$ with $\mathbf{4}, \mathbf{5}, \mathbf{7}$. This finding is in good correlation with that of ${ }^{1} \mathrm{H}$ NMR titration experiment, showing widened NMR peaks.

\section{Conclusions}

Comparing titration results to those of NMR and redox studies, one may come to the following conclusions. First, the thermodynamics of the complex formation in all cases is in the agreement with the literature data, depending on the ion radii and the crown ether hole size. Further, the NMR and redox experiments show that in spite of the predictable equilibrium effects sterically constrained crown ether demonstrate faster kinetics of the complex formation, that might be useful for the design of high-speed sensor systems.

Acknowledgements. Authors express their gratitude to the referee for comments that were very valuable for the discussion. Financial support from the Russian Scientific Foundation (projects No 18-73-00047) and equipment facilities from Center of collective facilities of A.N. Nesmeyanov Institute of Organoelement compounds of Russian Ministry of Sciences and High Education are gratefully acknowledged.

\section{References}

1. Izatt R.M., Pawlak K., Bradshaw J.S., Bruening R.L. Chem. Rev. 1995, 95, 2529-2586.

2. Izatt R.M., Bradshaw J.S., Pawlak K., Bruening R.L., Tarbet B.J. Chem. Rev. 1992, 92, 1261-1354.

3. Izatt R.M., Pawlak K., Bradshaw J.S., Bruening R.L. Chem. Rev. 1991, 91, 1721-2085.

4. Pedersen C.J. J. Am. Chem. Soc. 1967, 89, 7017-7036.

5. Atta N.F., Galal A., Ahmed Y.M. J. Electrochem. Soc. 2019, 166, B623-B630.

6. González-Calabuig A., Guerrero D., Serrano N., del Valle M. Electroanalysis 2016, 28, 663-670.

7. Weissenstein A., Saha-Mueller C.R., Wuerthner F. Chem. Eur. J. 2018, 24, 8009-8016.

8. Ilisz I.n., Péter A., Lindner W. TrAC, Trends Anal. Chem. 2016, 81, 11-22. 
9. Casas-Hinestroza J.L., Bueno M., Ibanez E., Cifuentes A. Anal. Chim. Acta 2019, 1081, 32-50.

10. Chehardoli G., Bahmani A. Supramol. Chem. 2019, 31, 221-238.

11. Yoo C., Dodge H.M., Miller A.J.M. Chem. Commun. 2019, 55, 5047-5059.

12. Shokurov A.V., Kutsybala D.S., Martynov A.G., Raitman O.A., Arslanov V.V., Gorbunova Y.G., Tsivadze A.Y., Selektor S.L. Thin Solid Films 2019, 692, 137591.

13. Safonova E.A., Polovkova M.A., Martynov A.G., Gorbunova Y.G., Tsivadze A.Y. Dalton Trans. 2018, 47, 15226-15231.

14. Fedorov Y.V., Fedorova O.A., Andryukhina E.N., Shepel N.E., Mashura M.M., Gromov S.P., Kuzmina L.G., Churakov A.V., Howard J.A.K., Marmois E., Oberle J. J. Phys. Org. Chem. 2005, 18, 1032-1041.

15. Mallory F.B., Mallory C.W. Photocyclization of Stilbenes and Related Molecules. In: Organic Reactions. Vol. 30. (Douben W.G., Ed.) New York: William-Blackwell, 1984. p. 1-456.

16. Dyachenko N.V., Khoroshutin A.V., Sotnikova Y.A., Karnoukhova V.A., Tokarev S.D., Anisimov A.V., Fedorov Y.V., Fedorova O.A. Photochem. Photobiol. Sci. 2019, 18, 2901-2911.

17. Gromov S.P., Vedernikov A.I., Kuz'Mina L.G., Lobova N.A., Basok S.S., Strelenko Yu.A., Alfimov M.V. Russ. Chem. Bull. 2009, 58, 108-114.

18. Armarego W.L.E., Chai C.L.L. Purification of Laboratory Chemicals, 5 ed., Butterworth Heinemann, Amsterdam, 2003, p. 80-388.

19. Belyakov P.A., Kadentsev V.I., Chizhov A.O., Kolotyrkina N.Y.G., Shashkov A.S., Ananikov V.P. Mendeleev Commun. 2010, 20, 125-131.

20. Gampp H., Maeder M., Meyer C.J., Zuberbuhler A.D. Talanta 1985, 32, 95-101.
21. Younes A.H., Zhang L., Clark R.J., Davidson M.W., Zhu L. Org. Biomol. Chem. 2010, 8, 5431-5441.

22. Wada F., Hirayama H., Namiki H., Kikukawa K., Matsuda T. Bull. Chem. Soc. Jpn. 1980, 53, 1473-1474.

23. Marzinzik A.L., Rademacher P. Synthesis 1995, 1995, 1131-1134.

24. Maryanoff B.E., Reitz A.B. Chem. Rev. 1989, 89, 863-927.

25. Wadsworth Jr W.S. Org. React. 2005, 73-253.

26. Frisch M.J., Trucks G.W., Schlegel H.B., Scuseria G.E., Robb M.A., Cheeseman J.R., Scalmani G., Barone V., Mennucci B., Petersson G.A., Nakatsuji H., Caricato M., Li X., Hratchian H.P., Izmaylov A.F., Bloino J., Zheng G., Sonnenberg J.L., Hada M., Ehara M., Toyota K., Fukuda R., Hasegawa J., Ishida M., Nakajima T., Honda Y., Kitao O., Nakai H., Vreven T., Montgomery J.A.J., Peralta J.E., Ogliaro F., Bearpark M., Heyd J.J., Brothers E., Kudin K.N., Staroverov V.N., Keith T., Kobayashi R., Normand J., Raghavachari K., Rendell A., Burant J.C., Iyengar S.S., Tomasi J., Cossi M., Rega N., Millam J.M., Klene M., Knox J.E., Cross J.B., Bakken V., Adamo C., Jaramillo J., Gomperts R., Stratmann R.E., Yazyev O., Austin A.J., Cammi R., Pomelli C., Ochterski J.W., Martin R.L., Morokuma K., Zakrzewski V.G., Voth G.A., Salvador P., Dannenberg J.J., Dapprich S., Daniels A.D., Farkas O., Foresman J.B., Ortiz J.V., Cioslowski J., Fox D.J., Gaussian 09, Revision B.01 ed., Gaussian, Inc., Wallingford CT, 2010.

27. Lukovskaya E.V., Bobylyova A.A., Fedorova O.A., Fedorov Y.V., Kardashev S.V., Maksimov A.L., Anisimov A.V., Maurel F., Marmois E., Jonusauskas G., Didane Y., Brisset H., Fages F. Synth. Met. 2007, 157, 885-893.

28. Amini M.K., Shamsipur M. J. Phys. Chem. 1991, 95, 9601-9604.

29. Marcus Y. Chem. Rev. 1988, 88, 1475-1498. 